Journal of Finance and Banking Review

Journal homepage: www.gatrenterprise.com/GATRJournals/index.html

J. Fin. Bank. Review 1 (1) 11 - 16 (2016)

\title{
Performance Improvement for Micro, Small and Medium Enterprises (SMEs) with Social Financing Model
}

\author{
Falikhatun $^{1 *}$, Yasmin Umar Assegaff ${ }^{2}$ and Hasim ${ }^{3}$ \\ ${ }^{1}$ Business and Economic Faculty and Peer Group of Center for Islamic Economic Studies Universitas Sebelas Maret, Surakarta, \\ Indonesia
}

\begin{abstract}
Objective - This study aims to analyze the implementation of Qardhul Hasan in Islamic Banking in Indonesia. This study uses the phenomenology approach to explain the phenomenon.

Methodology/Technique - Data were collected through in-depth interviews, observation, and documentation and analysis was conducted using the Interpretative Phenomenological Analysis (IPA) and the Sharia Analysis.

Findings - Results drawn from the Interpretative Phenomenological Analysis (IPA) show that: (1) The meanings of Qardhul Hasan in Islamic Banking in Indonesia are diverse. Qardhul Hasan was interpreted as loans and charity. The sources of fund drawn from the Qardhul Hasan sources in Islamic Banking in Indonesia originated from Infaq, charity, non-halal funds, fines, and donations. Qardhul Hasan in Islamic Banking in Indonesia was implemented with two models: Productive Loan Fund Distribution and Social Fund Distribution. From the Sharia Analysis, it was noted that most of the Qardhul Hasan objects were approved by the Islamic Economic Theory.

Novelty - The novelty of this study lies in the analysis results which proposed that (1) Qardhul Hasan should be interpreted according to its goodness principles, (2) Source of Funds for Qardhul Hasan should come from ZISW AF, and (3) The model of empowerment should be developed according to the needs of the Indonesian population, especially as a maritime country
\end{abstract}

Type of Paper: Empirical

Keywords: Performance, SMEs, Social Financing Model, Sharia Analysis, Interpretative Phenomenological Analysis. JEL Classification: M13, P31.

\section{Introduction}

Qardhul Hasan is a feature that distinguishes Islamic Banks from conventional banks. Besides its commercial mission, Qardhul Hasan also has a social mission which is to improve the image of Islamic Banks and to raise community loyalty toward using Islamic Banks (Antonio, 2001, p. 88). According to Karim (2007, p. 68), Qardhul Hasan is an agreement to lend money but in essence, Qardhul Hasan is a charity because the contract does not require repayment. However, several countries like Malaysia and those in the Middle East do not distinguish the difference between Qardh and Qardhul Hasan.

\footnotetext{
* Paper Info: Received: September 15, 2016

Accepted: December 12, 2016

* Corresponding author:

E-mail: falie_008@yahoo.com

Affiliation: Business and Economic Faculty, Universitas Sebelas Maret, Indonesia
} 
Previous literature review indicates that the concept of Qardhul Hasan is relatively rare in research when it is compared with other funding products such as Murabahah, Mudharabah, Istisna', and Ijarah. Material discussion is stated more in text books (Karim, 2007; Antonio, 2000 cited in Ariffin and Adnan, 2009) and of the literature that can be accessed, it is Zaher and Hassan's (2001) study which talks about the Islamic financial system in Islamic countries such Iran, Sudan, Egypt, Pakistan, and Indonesia. Based on research results, it can thus be concluded that the Qardhul Hasan agreement gives very small returns in banking. In fact, it can even become a negative net present value in Islamic Bank's investments, thus it is unpopular in many banks in Islamic countries.

Another study by Santoso (2005) examined the Qardhul Hasan funding agreement that was implemented in the PT. Bank BRI Syariah in the Semarang branch. The study concluded that the Qardhul Hasan funding were given to groups of weak economy entrepreneurs who were not given credit by conventional banks to do business. The maximum amount given is one million rupiah. Following this is another study by Mirachor and Iqbal (2007) who looked at Islamic Banks in Iran. They identified several Qardhul Hasan characteristics, one of which is the flexibility of Qardhul Hasan. When Qardhul Hasan is tied to guarantees, it appears that only a commitment from the creditors, in the form of a simple contact is required since no physical guarantee is involved. In this regard, a simple documentation procedure is involved, with small amount of loans approved and fast cash reimbursement procedure with no interest. However, a one $\%$ fee may be added to cover administrative expenses and to gain easier access to funds for local debtors and this should be explained by fund managers to investors.

Farooq (2008) wrote about Qardhul Hasan, Wadiah/Amanah, and Bank Deposits, stating that there were four big problems related to the Qardhul Hasan financing. These problems include administration fee, some added payment which should be settled prior to maturity, and guarantors. In another study, Arrifin, and Adnan (2009) examined Islam banker's perception toward Qardhul Hasan by surveying 300 bankers involved with 13 general Sharia banks in Malaysia. The data were collected using questionnaires and the response rate was 46.9\%. From the study, three conclusions were drawn: (1) knowledge and awareness of Islam bankers toward Qardhul Hasan, (2) problems related with Qardhul Hasan, and (3) differences in perception between Islamic bankers in Malaysia. In looking at the problems related to Qardhul Hasan, it appears that the Qardhul Hasan agreement does not generate profits, does not cover transaction expenses, does not gain any support from top management, and there is a low demand for this kind of agreement. This did not make any difference in the perceptions of those in the top, middle, or lower management, among bankers in Islamic Banks in Malaysia. These personnels had assumed that Qardhul Hasan is the same as Corporate Social Responsibility (CSR).

A subsequent study by Farah (2009) noted the benefits of the Al Qardh, i.e. (1) the amount of loans granted are usually bigger than the Shadaqah, (2) the loans are realized as revolving funds, and (3) increased marginal propensity for consumption by the poor. In another study, Amin et al., (2010) focused on attitude, subjective norms, and the Qardhul Hasan's financing price. Their results showed that attitude is significantly associated with the Qardhul Hasan's financing demand. The higher the positive attitude, the higher the bank customer's demand for Qardhul Hasan financing. The study then conclude that the subjective norm is significantly related to the Qardhul Hasan's financing demand. Meanwhile, the Qardhul Hasan's financing price is significantly related to the Qardhul Hasan's financing demand. This was ascertained by Ibrahim and Noor (2011) who conducted a study in Malaysia's Sharia banking and they noted that the Qardhul Hasan is a loan instrument for checking accounts and this can be used by banks with the customers' agreement. The money borrowed will be returned in the same amount as the amount lent. The last study was the one conducted by Febianto and Ashany (2012). Their study was based on a case study located in Dompet Dhuafa, West Java, Indonesia. The study examined Qardhul Hasan financing with Zakah funds. They concluded that the Qardhul Hasan financing implementation can improve economic empowerment.

Previous studies have also examined several other topics including the mechanism and procedure of Qardhul Hasan (Zaher \& Hasan, 2001; Santoso, 2005; Ariffin \& Adnan, 2009; Jalil \& Rahman, 2010; Onagun, 2011) both in terms of the objective or the loan recipients. 
The next section focuses on the methodology. In most research that involve the Qardhul Hasan, the methodology used is often literature study (Asgary, 2007; Mirachor, et al., 2007; Mustafa \& Ismailov, 2008; Farah, 2009; Jalil Md, et al., 2010; and Onagun, 2011), surveys (Zaher, et al., 2001; Abdullah, et al., 2007; Ariffin, et al., 2009; and Amin et al., 2010), and case studies (Santoso, 2005; Febianto \& Ashany, 2012).

Based on these studies, it is thus deduced that exploring the Qardhul Hasan problem descriptively cannot capture the hidden phenomenon. Hence, this study will try to investigate a deeper and more detailed understanding of the meaning that Muqridh understood and experienced in Qardhul Hasan's financing model on Sharia banking. Therefore, the research questions that will be examined in this research are:

(1) How does Muqridh interpret the Qardhul Hasan's financing on Sharia banking?

(2) How is the implementation of the Qardhul Hasan financing models as an effort of poverty alleviation undertaken by Indonesia's Sharia Banks?

Ismail (2010, p. 72) stated that Qardhul Hasan is a beautiful loan that is primarily a business transaction which establishes the relationship between a lender and a borrower. Meanwhile, Abdul Rahman (2006) defined Qardhul Hasan as the transfer of ownership of an asset or money from the original owner to others, on condition that, the asset or money will be returned to the owner in the same condition/form/value as when it was first received by the other party.

Amanah is something that is left to the others to be maintained and returned when the time comes or when requested by the owner (Shihab, 2002, p. 457). In relation to Islamic Banking, the Amanah Principle can be manifested in the form of not accepting gifts or commissions in the business lobby and by not taking ribaa or accepting a bribe, not cheat, not to dhalim from the start of the input and the process, and the output must be free from haraam transactions and services.

Maslahah are all forms of condition, both material and non-material, which can improve the human position as the noblest creature. The essence of the theory of Maslahah in economic activity is the achievement of human welfare which lies in the protection of five things namely: religion (ad-dien), soul/life (an-nafs), intellectual (al-'aql), family and descendants (an-nasl), and property (an-Naml) (as-Syatibi, in P3EI, 2008:54).

Maslahah, at the implementation stage, can be divided into three levels namely: Level one - Maslahah Dharuriyah which concerns all aspects that are essential for human life, and therefore must exist as an essential condition of life manifestation and human benefits, both worldly and hereafter. Level two - Maslahah Hajiyyah is everything that becomes the basic necessity (principal) of human life so that humans can enjoy a happy and prosperous present life and afterlife, and to avoid poverty. If this necessity is not obtained, it will threaten the survival indirectly and human's life becomes less powerful. Level three - Maslahah Tahsiniyah which is a necessity of life that is complementary in nature (as a supplement) and it further refines the welfare of human life. If this benefit is not met, then the human life is less beautiful and less enjoyable although it will not cause a mudharat and a destruction in life.

\section{Method}

This study is qualitative in nature and it uses natural backgrounds as a research site for the purpose of interpreting the phenomena. The study is carried out with the involvement of various other methods including the interpretive paradigm which is based on the belief that individuals (human) are creatures that are socially and symbolically established and who maintain their own reality (Mulyana, 2011, p. 8). The approach this study uses is termed as phenomenology, an approach pioneered by Edmund Husserl (1859-1938) (Moran, 2000 , p. 1). The phenomenological approach tries to express the meaning of one's experience. The meaning of something that is experienced by a person depends on how people relate to that something (Edgar \& Sedgwick, 1999, p. 273). This study involves the participation of several Islamic Banks in Indonesia including the PT BMI and PT Bank Negara Indonesia Syariah. Data were collected via in-depth interviews, observations and documentations.

The approach used for analysis includes the IPA (Interpretative Phenomenological Analysis) approach which aims to explore in detail, how one understands self and their surroundings, and about the meaning of 
their experiences of something. The main target of this study is the meaning of the experiences, events, and status held by participants. The Sharia Analysis is an approach that is based on the al-Qur'an, as-Sunna, and al-Ijtihad. Following this, the study uses Smith's (2009, p. 79-107) Interpretative Phenomenological Analysis to analyse data.

\section{Result}

From the analysis conducted, it appears that the meaning of Qardhul Hasan for Muqtaridh was based on some basic principles drawn from the al-Quran and this was then applied as a financing base for Qardhul Hasan. These principles include:

a. The responsibility of the self, aside from his/her zakat responsibility for the poor and the needy which is not to acquire their property because they have already failed in their business and yet these individuals are not asking for help from others.

b. The rights in Muslim people's wealth. They have divided their welfare into two parts because they were sure that some parts of their wealth were the poor's right, whether they asked or not. This action proves that they try to release their misery and celebrate freedom by not being greedy. This action also shows the presence of responsibility for the capable towards the incapable, among people who guarantee and support each other. The poor who asked and the pauper who does not want to ask, without telling about his/her need, is still not asking for help maybe because he/she is involved in a disaster and as a consequence, became poor.

c. The motive of distribution, and also to lay down rules in the law system and shariat. One of those rules is the regulation of economic system which represents one of the big parts of Islamic economy principles. The private ownership in this system is being recognized, but it is also restricted. The objective of this rule is to make sure that the wealth is distributed widely in society and not just among the rich.

d. Two main conditions can be drawn from the authentic shalat fulfillment. First, sincerity in doing it because of Allah. Second, to be experienced with the weak's needs and willingness so as to help even the smallest. From Asbabun Nuzul, this verse explains condemnation to those who provide assistance but not for those desired by Allah.

Further, according to the results of the IPA, several propositions can be drawn regarding the definition and experience of Muqridh in the Qardhul Hasan funding:

The Muslim's responsibility is not only zakat in particular, but also setting aside certain amount of their wealth for the poor, both for those who ask for alms and those who do not. This action proves that one who has been freed from his/her miserly state and and greed is relieved. This also shows that Muslims have the responsibility, especially for those with financial capabilities, to take care of those who have weak financial capabilities, thereby creating an environment of Muslims who help each other. It also includes helping the poor who asked for alms, the poor who did not aks for aims and those who had experienced disaster and became poor.

There are rules in Islam which acknowledges personal ownership or wealth owned by individuals, but there is a restriction to its use. The aim of this rule is to avoid limited circulation of money in the high social class so that the welfare will be circulated evenly within the community. One of the means to achieve this objective is by providing alms for people who need financial aids. 
Two main requirements or main essence of shalat are: 1) sincerity in performing Islamic rules for Allah; and 2) feeling poor people's needs and the willingness to provide alms even if it is in a small amount.

The above propositions are not directly related to the definition of Qardhul Hasan. However, from those statements it can be deduced that Muqridh understanding and Qardhul Hasan are both defined as loan and charity. But implicitly, the basic principles of Qardhul Hasan in Sharia Banking are empathy, responsibility, and requirement to distribute rich people's welfare for the people in need. The aim of the Qardhul Hasan is to elevate Mustahiq into Muzakki.

The definition of Qardhul Hasan provided here is substantially in line with previous studies and this inlcudes:

1) Qardhul Hasan are charitable loans with no interest, or a zero-interest bearing loan, with low expectations of return of capital (Iqbal \& Abas, 2007 and AAOIFI, 2008).

2) Qardhul Hasan can also be defined purely as a benevolent act, and it is extended to others without interest or any other compensation from the borrower and reward can be expected only from God (Askari, Hossein., Iqbal, Zamir, Mirakhor and Abas, 2008).

The target of the Qardhul Hasan funding are those who are in the eight asnaf, especially for Fakir and Miskin. When the analysis is studied deeper, it appears that according to published financial statements, the source of funds for Qardhul Hasan are from Infaq, Charity, Fines, Non Halal Funds, and other donations. The implementation of the Qardhul Hasan funds mostly came from Zakat, Infaq, Charity, and Wakaf. Furthermore, in Islamic Banking Indonesia, Qardhul Hasan funds are distributed in two different distribution models:

a. Productive Loan Fund Distribution

Productive loan is a loan that continually produces goods or it helps to improve goods production.

b. Social Fund Distribution

Social fund is fund distribution only for people who need consumption or to meet their urgent needs.

Distribution target for Qardhul Hasan funds are for people who are in the eight asnaf classifications. Qardhul Hasan funds are obtained from all Islamic Banking employees' zakat.

\section{Discussion}

The model for implementing the Qardhul Hasan is in accordance with the Amanah principles (QS. 8, p. 27) which state that human to human amanah covers large fields, not only in deposited wealth, or agreement, but also stated secrets. Amanah also indicates individuals' realization of their role as the representative of Allah SWT and that as human beings, they need to play their roles according to God's prevailing rules (Triyuwono, 2006, p. 183). When customers' and employees' deposit funds, in this term as an amah from them, the funds are utilized according to the objectives, thus it means that Sharia Banking has been amanah towards their customers. Next, in its relation with the Maslahah theory, the model used is in accordance with the theory. It is reflected in the implementation of the Productive Loan and Social Funds Distribution which are related to the optimization of funding benefits performed by Sharia Banking (This is aimed at people who are in need and they are determined based on the priority scale). Thus, it will affect the increase in the number of community members who were released from their distress and had achieved an opportunity to work and find a job.

The conclusions that can be drawn from the analysis encompass:

1) Qardhul Hasan is a beautiful loan that is primarily a business transaction that establishes a relationship between lender and borrower.

2) According to the experience of Muqridh, Qardhul Hasan as noted in Islamic Banking in Indonesia, is implemented through the Productive Loan Fund Distribution and Social Fund Distribution. 
3) Finally, based on the Sharia Analysis, most of the Qardhul Hasan objects were approved by the Islamic Economic Theory.

Suggestions drawn from this study are primarily to propose that future researcher develop a cooperation with institutional research centres particularly in areas related to Islamic Banking, Islamic Banking products, Supervision of Islamic Banking, and Accounting for Islamic Banking.

\section{References}

Amin, H., Ghazali, M., \& Supinah, R. (2010). Determinants of Qardhul Hassan financing acceptance among Malaysian bank customers: an empirical analysis.

Antonio, M. S. (2000a). Bank Syariah: Suatu Pengenalan Umum. Jakarta: Penerbit Tazkia Institute.

Antonio, M. S. (2001b). Bank Syariah: Dari Teori ke Praktik. Jakarta: Gema Insani.

Ariffin, N.M. \& Adnan, M.A. (2009). The perceptions of Islamic Bankers on Qardhul Hasan in Malaysian Islamic Banks. www.googlescholar.com

Asgary, A. (2007). Informal Microfinance Institutions: Case of Qard hasan Funds in Iran: in Non-bank Financial Institutions: Islamic Alternatives. Islamic Research and Training Institute, Jeddah, Saudi Arabia.

Edgar, A \& Sedgwick, P (1999). Key Concept in Cultural Theory. London and New York: Routledge, Taylor \& Francis Group.

Farah, A.F. M. (2009). Charitable Investment Banking Model: An Islamic Perspective. Conference of Islamic Perspective on Management and Finance, 2 - 3 July 2009.

Farooq, M.O. (2008). Qardh al-Hasana, Wadiah/Amanah and Bank Deposit: Apllication and Misapplication of Some Concepts in Islamic Banking. Harvard Islamic Forum, April 19 - 20, 2008. www.srrn-1d1418202-1,pdf

Febianto, I. \& Ashany, A.M. (2012). The Impact of Qardhul Hasan Financing using Zakah Funds on Economics Empowerment (Case Study of Dompet Dhuafa, West Java, Indonesia), Asian Business Review, 1(1), 15 - 20.

Jalil, A. M. (2010). Financial Transaction in Islamic Banking are Viable alternatif to the Conventional Banking Transaction. http://www.ijjbssnet.com.

Karim A. A. (2007). Bank Islam: Analisis Fiqih dan Keuangan. Penerbit: PT Rajagrafindo Persada, Jakarta.

Mirachor, A. \& Iqbal, Z. (2007). Qardhul Hasan Microfinance. New Horizon, April-Juni, 2007.

Moran, D. (2000). Introduction to Phenomenology. London and New York: Routledge, Taylor \& Francis Group.

Mulyana, D. (2011). Landasan Filsafat Metode Penelitian Kualitatif. Paper disampaikan pada Seminar Nasional Metode Penelitian Kualitatif, tanggal 9 Juni 2011.

Mustafa, Z. \& Ismailov, N. (2008). Entrepreneurship and Microfinance a tool for Empowerman of Poor: Case of Akhuwat-Pakistan. www.srrn.com

Santoso, A.Y. (2005). Pelaksanaan Akad Pembiayaan Qardh pada Bank BRI Syariah Cabang Semarang. Thesis, Program Pasca Universitas Diponegoro, Semarang. http://eprints.undip.ac.id/15354/1/Andita_Yuni_Santosa.pdf

Smith, J. A., Flowers, P. \& Larkin, M. (2009). Interpretative Phenomenological Analysis: Theory, Method and Research. Los Angeles, London, New Delhi, Singapore, Washington: Sage.

Onagun, A. I. (2011). Solvency of Takaful fund: A Case of Subordinate Qard. Proceeding of $2^{\text {nd }}$ International Conference on Business and Economic Research, Kuala Lumpur, Malaysia.

Zaher, T. S. \& Hasan, M. K. (2001). A Comparative Study of Islamic Bank Practice, Financial Market, Institution and Instrument, 10(4), 155-199. 